\title{
Examining plant variety protection in Nigeria: Realities, obligations and prospects
}

\section{Titilayo Adebola}

School of Law, The University of Warwick, Coventry, United Kingdom

\section{Correspondence}

Titilayo Adebola, School of Law, The University of Warwick, Coventry. CV4 7AL. United Kingdom.

Email: titilayoadebola@gmail.com
Nigeria does not currently have a plant variety protection system. Three key reasons why Nigerian law and policy makers should pay attention to plant variety protection are the country's evolving agricultural sector, susceptibility to external pressures and pending international obligations. From 2010, successive Nigerian governments have promoted private sector investments in agriculture, contributing to the increase in the number of agribusinesses in the country. Agribusinesses tend to lobby for the introduction or reform of national plant variety protection systems to suit their business interests. Furthermore, as a founding member of the World Trade Organization (WTO), Nigeria has a pending obligation under Article 27.3(b) of the Agreement on Trade-Related Aspects of Intellectual Property Rights (TRIPS) to protect plant varieties through a patent system, a sui generis system, or a combination of systems. This article argues that Nigeria should proactively introduce a plant variety protection system designed to suit its socioeconomic realities before it is pressured to adopt an unsuitable system. In assessing the options under TRIPS vis-a-vis the small-scale centered agricultural sector in Nigeria, the article finds that the best-suited option for the country is a sui generis system which protects the interests of both small-scale farmers and agribusinesses.

\section{KEYWORDS}

access and benefit sharing, farmers' rights, Nigeria, plant breeder's rights, plant variety protection, TRIPS 


\section{1 | INTRODUCTION}

Agriculture is a historically significant sector in Nigeria. Before the discovery of oil in the 1960s, it was the mainstay of the economy (Ayoola, 2001; Ekekewe, 1985). Although the discovery of oil in commercial quantities led to the decline in the exportation of agricultural products such as cocoa, cotton, groundnuts, palm kernel, palm oil and rubber, there was a seminal resurgence in agricultural prominence from 2010 (Agricultural Research Council of Nigeria, 2010). Plant varieties embodied in bulbs, cuttings, seeds and other plant-propagating materials are the core of agricultural innovation on which food supply and agricultural products depend. ${ }^{1}$ Small-scale farmers, agribusinesses and scientists continually select, save and recombine plant varieties to increase productivity as environmental conditions and commercial preferences evolve (Ramanna \& Smale 2004; Rangnekar, 2002). While stakeholders in Nigeria's agricultural sector benefit from access to new plant varieties, there is limited awareness about plant variety protection in the country (NACGRAB, 2016a Nnadozie, Lettington, Bruch, Bass, \& King, 2003). ${ }^{2}$

This article emphasizes three key reasons for the introduction of a suitable plant variety protection system in Nigeria. First, its recent focus on agricultural transformation which has incentivized national and international investments. Second, its susceptibility to external pressures, including from agribusinesses, the International Union for the Protection of New Varieties of Plants (UPOV) Office, as well as trade and investment agreements, which tend to promote the patent system or the plant breeder's rights system set out in the 1991 International Convention on the Protection of New Plant Varieties (UPOV, 1991 Convention) (Correa et al., 2015). Third, its pending obligation to protect plant varieties under Article 27.3(b) of the World Trade Organization's (WTO) Agreement on Trade-Related Aspects of Intellectual Property Rights (TRIPS). ${ }^{3}$ As a developing country WTO member, Nigeria ought to have implemented its TRIPS obligations by 1 January 2000. However, multiple reasons including military dictatorships, political instability and lack of interested actors have contributed to the absence of plant variety protection in the country. ${ }^{4}$

The article argues that Nigeria should proactively introduce a plant variety protection system suited to its socio-economic realities before it is pressured to adopt the patent system or the plant breeder's rights system which are unsuitable to its small-scale farmer centered agriculture sector. Small-scale farmers varieties either do not meet the stipulated conditions for protection or their traditional farming practices such as saving, reusing, exchanging and selling farm-saved seeds are restricted under these systems. As such, the patent system and plant breeder rights system are better suited to countries with industrialized agricultural sectors dominated by agribusinesses.

For conceptual clarity, it is important to delineate the application of the terms small-scale farmers and agribusinesses. Small-scale farmers (also called smallholders) refer to subsistence farmers who mainly use simple farming tools and employ labor-intensive agroecological farming practices (IFAD, 2013; Mgbenka \& Mbah, 2016). Although landholding, such as 0-10 hectares under cultivation is a useful metric for definition, small-scale farmers' landholding differs depending on the context (Lowder, Skoet, \& Singh, 2014; Murphy, 2012). Other key characteristics of small-scale farmers include their practices of saving, reusing, exchanging and selling seeds. Agribusinesses refer to seed and farm chemical businesses engaged in the supply of seeds, pesticides and fertilizers, such as BASF, Bayer, Dow, Dupont, Monsanto and Syngenta (Favereto, 2016; Zylbersztajn, 2017). The increasing prominence of agribusinesses reflects the shift in agricultural innovation from the farms to labs, the transition of farmers from seed savers to seed purchasers and the growth in profit-oriented industrialized agriculture (Fowler, 1994; Kloppenburg, 2004). ${ }^{5}$

This article is divided into three parts. Part I provides a background on Nigeria's agricultural policies from 2010 which have informed the increase in agricultural investments in the country. Part II discusses Nigeria's international obligations related to plant variety protection. Part III explores the plant variety protection landscape in Nigeria, including the current position of the law and attempts to introduce plant variety protection through IPRs reforms. The article makes an original contribution to the literature on plant variety protection in the Global South, by analyzing the timely, yet under-explored case of Nigeria. 


\section{2 | BACKGROUND ON AGRICULTURAL POLICIES IN NIGERIA}

After years of neglect, in 2010, the Federal Government of Nigeria under President Goodluck Ebele Jonathan's administration recommitted to reform its agricultural sector (The Transformation Agenda, 2011-2015). Apart from the potential increase in food production to meet the food and nutrition needs of Nigerians, there are further good reasons for his focus on agriculture. There is high growth potential for agriculture in Nigeria. Nigeria has large land mass: 84 million hectares of arable land out of which only $40 \%$ is cultivated, abundant water resources: 230 billion cubic meters of water, and rich biodiversity: plants, animals, fungi and microbial species (Federal Ministry of Agriculture and Rural Development [FMARD], 2017). Agriculture is also a significant employer of labor. As of 2016, about $30 \%$ of the population was engaged in agriculture (World Bank, 2016). Agriculture has the potential to provide gainful employment for even more Nigerians (Ogbalubi \& Wokocha, 2013). Furthermore, agriculture provides a sustainable diversification option for Nigeria because it has both the natural and human resources required to unlock its agricultural potentials. Before Nigeria turned to oil in the 1960s, it was a leading exporter of cocoa, cotton, palm oil, groundnut and rubber (Ayoola, 2001; Helleiner, 1966). Unlocking its agricultural potential can significantly contribute to Nigeria's economic growth in the face of the volatility in international oil prices. ${ }^{6}$

It is against this background that President Jonathan's administration introduced the Agriculture Transformation Agenda (ATA) which focused on building agriculture as a business through investment-driven strategic partnerships with the private sector (ATA 2011-2015). ${ }^{7}$ Policy goals of the ATA included: integrating food production, storage, food processing and industrial manufacturing value chains referred to as "farm-to-fork," and creating incentives for private sector participation such as $0 \%$ duty on all agricultural machinery and equipment. One of the key achievements of the ATA was the restructuring of the federal fertilizer procurement system through the Growth Enhancement Support (GES) scheme launched by the then minister of agriculture (and current president of the African Development Bank), Dr Akinwunmi Adesina in 2012. The GES scheme introduced the first electronic voucher (E-wallet) input system for farmers. In other words, the government stopped its procurement and distribution of seed and fertilizers. Private sector seed and fertilizer companies directly sold inputs to farmers through their mobile phones. Nigeria was the first country in Africa to develop the E-wallet system. Adesina points out that 1.5 million small-scale farmers received subsidized seeds and fertilizer via the E-wallet scheme in 2012 (Adesina, 2013). ${ }^{8}$

Following the change in administration in 2015, President Muhammadu Buhari introduced the Agriculture Promotion Policy 2016-2020 (APP) in 2016. The APP focuses on closing the demand-supply gaps between crop and livestock production, which includes tackling input, finance, storage, transport and market access problems in key value chains. Three main pillars of the APP are as follows: (i) Productivity enhancement: through access to land, access to inputs, as well as provision of efficient storage, processing and marketing facilities; (ii) Crowding in private sector investment: through access to finance and agribusiness investment development; and (iii) Institutional coordination of the FMARD with other ministries such as the Federal Ministry of Power, Works and Housing; the Federal Ministry of Transportation; and the Federal Ministry of Industry, Trade and Investment. Ultimately, the APP prioritizes the promotion of agribusiness investments, food security, import substitution, job creation and economic diversification (APP 2016-2020).

The ATA and APP have incentivized both domestic and foreign investments in Nigeria's agricultural sector. Companies registered to produce certified seed in Nigeria increased from 13 in 2011 to 134 in 2014 (Bentley, Ajayi, \& Adelugba, 2011; NASC Annual Report, 2014). Notably, international agribusinesses such as Cargill, Syngenta and Monsanto have opened offices in Nigeria. Scholars such as Cary Fowler, Graham Dutfield and Jack Kloppenburg note that agribusinesses tend to lobby for the extension of intellectual property (IP) protection to new plant varieties at the national and international levels (Dutfield, 2003; Fowler, 1994; Kloppenburg, 2004). The agribusinesses assert that the extension of IP to plant varieties is an incentive (and reward) for investment in research and development of new plant varieties (Correa et al., 2015; Helfer, 2004a). While Nigeria's agricultural transformation leading to the proliferation of agribusinesses portend pressure to introduce the patent system or the UPOV plant breeder's rights 
system which are reasons proffered for the proactive introduction of plant variety protection, another reason is the country's pending international obligations as discussed below.

\section{I GLOBAL LEGAL ARCHITECTURE FOR PLANT VARIETIES AND NIGERIA}

As a founding WTO member, Nigeria has a pending obligation to protect plant varieties, as set out in Article 27.3(b) of TRIPS. ${ }^{9}$ Article 27.3(b) of TRIPS obliges all WTO members inter alia to protect plant varieties through a patent system, an effective sui generis system, or a combination of systems. Nigeria, categorized as a developing country in the WTO, had up to 1 January 2000 to fulfil this obligation. ${ }^{10}$ However, it failed to meet the deadline. It seems that there is no immediate penalty for missing the deadline because no WTO member has instituted an action in this regard at the WTO Dispute Settlement Body. ${ }^{11}$

Although prima facie, Article 27.3(b) of TRIPS offers choice; it raises more complex debates about the NorthSouth divergence on plant variety protection. That is, debates between industrialized Global North (such as the United States, European Union [EU], Japan and Canada) which has an average 4\% farming population and less industrialized Global South (such as African countries, parts of Asia and Latin America) which has an average 60\% farming population (World Bank, 2017). As Peter Drahos and Philippe Cullet rightly point out, plant variety protection was alien to countries in the Global South before TRIPS (Cullet, 2001; Drahos, 1995). ${ }^{12}$ The extension of IPRs to plant varieties originated in the United States and Europe in the twentieth century. The US Plant Patent Act (1930) was the first IPRs system for plant varieties in the world, while early European plant variety protection systems include the Netherland's Plant Breeder's Rights Act 1942, Germany's Seed Act 1953 and the UPOV Plant Breeder's Rights' system 1961 (Dutfield, 2003; Sandersen 2017; Van Overwalle, 1999). ${ }^{13}$ Following the 1980 Diamond v Chakrabarty ${ }^{14}$ case, the US extended patents to living materials. ${ }^{15}$ Conversely, Article 53(b) of the European Patent Convention 1973, prohibited patents for plant varieties in the EU. The discord between the United States and the EU over patenting plant varieties resulted in the apparent latitude in Article 27.3(b) of TRIPS (Gervais, 1998; UNCTAD-ICTSD, 2005).

From the early 1980s, countries in the Global South began to question the asymmetry in IPRs for plant varieties (Pistorius \& Wijk, 1999). These countries were concerned about the free flow of genetic resources predominantly from the Global South to the Global North, with no returns to the Global South (Bragdon, Garforth, \& Haapala, 2008). ${ }^{16}$ As a result, activists such as Pat Mooney, Cary Fowler and Hope Shand, alongside civil society organizations (CSOs) such as Rural Advancement Foundation International (RAFI), Genetic Resources Action International (GRAIN) and Community Technology Development Trust (CTDT) advocated for alternative legal norms and principles to protect interests of small-scale farmers, especially those in the Global South, who conserve and improve plant genetic resources. These alternative legal norms and principles, conceptualized as farmers' rights in the Food and Agriculture Organization's (FAO) International Undertaking (IU) on Plant Genetic Resources (1983) ${ }^{17}$ as well as access and benefit sharing in the Convention on Biological Diversity (CBD, 1992) ${ }^{18}$ were informed by values such as reward and recognition (Halewood \& Nnadozie, 2008; Mooney, 2011; Pistorius \& Wijk, 1999). Significantly, farmers' rights, as well as access and benefit sharing, seek to counterbalance the patent system and the UPOV plant breeder's rights system.

However, the definition of farmers' rights is vague, and its implementation is fraught with difficulties (Andersen, 2016a, 2016b; Borowaik, 2004; Peschard, 2014). ${ }^{19}$ As earlier mentioned, the term was coined in the 1980 s to counterbalance the IPRs for plant varieties and to recognize the contribution of small-scale farmers to the conservation and improvement of plant genetic resources (Mooney, 2011). Whereas agribusinesses could obtain IPRs for new varieties to reward time and expense invested in innovation, small-scale farmers had no equivalent reward system. Rather than lobby only for the creation of a new sui generis IPRs category for farmers, activists, the CSOs and Global South countries involved in farmers' rights advocacy also promoted these rights as a socio-political response to IPRs for plant varieties. The non-binding FAO Farmers' Rights Resolution 5/89 and 3/91 of the IU loosely referred to farmers' rights as rights arising from the past, present and future contributions of farmers' in conserving, improving 
and making available plant genetic resources, subject to national sovereignty. ${ }^{20}$ However, it was the legally binding International Treaty on Plant Genetic Resources for Food and Agriculture (ITPGRFA, 2001) ${ }^{21}$ that cemented farmers' rights into the global legal architecture for plant varieties. Nonetheless, like the previous FAO Resolutions, farmers' rights remained vague in the ITPGRFA.

The ITPGRFA frames farmers' rights as both IPRs and socio-political rights. Article 9 of the ITPGRFA provides for farmers to: (i) protect traditional knowledge relevant to plant genetic resources for food and agriculture; (ii) equally participate in sharing benefits arising from the utilization of plant genetic resources for food and agriculture; (iii) participate in decision making at the national level on matters related to the conservation and sustainable use of plant genetic resources for food and agriculture; as well as (iv) save, use, exchange and sell farm-saved seed/ propagating materials, subject to national law and as appropriate. ${ }^{22}$ The first right: (i) above is an IP right, while the other three: (ii) to (iv) are socio-political rights. However, Article 9 of the ITPGRFA leaves the implementation of these rights to the discretion of the contracting parties, without providing conditions, guidelines or timelines for implementation. In leaving the implementation of these rights to parties, Keith Aoki and Kennedy Luvai argue that the ITPGRFA is a vague commitment to farmers' rights (Aoki \& Luvai, 2007). ${ }^{23}$ Similarly, Chidi Oguamanam points out that the inclusion of subject to national law and as appropriate in Article 9.3 of the ITPGRFA allows competing national laws to take priority over the implementation of the ITPGRFA (Oguamanam, 2015).

Unlike farmers' rights, guidelines to implement access and benefit sharing principles provided in the CBD are set out in the Nagoya Protocol on Access to Genetic Resources and the Fair and Equitable Sharing of Benefits Arising from their Utilization (Nagoya Protocol) which entered into force in 2014. Simply put, access and benefit sharing refer to access to biological resources as well as the fair and equitable sharing of benefits arising from their utilization (Articles 1 and 2, CBD). ${ }^{24}$ While like the ITPGRFA, the CBD leaves the implementation of its access and benefit sharing provisions to contracting parties' discretion (Articles 15 and 22, CBD), the Nagoya Protocol further creates a framework for implementation. The Nagoya Protocol establishes predictable conditions for access to biological resources and ensures sharing of benefits when biological resources are obtained from its parties. For example, Article 6 of the Nagoya Protocol provides for prior informed consent from the country of origin as a condition for access to genetic resources; it also sets out the legislative, administrative or policy measures necessary to access such resources. While Article 14 of the Nagoya Protocol establishes an access and benefit clearinghouse, which is a platform for exchanging information and facilitating implementation of its objectives.

Following on from the above, although the obligation to protect plant varieties is set out in Article 27.3(b) of TRIPS, there are overlapping and non-hierarchical agreements that shape or constrain the design of plant variety protection systems, otherwise referred to as "regime complexes" (Raustiala \& Victor, 2004). Regime complexes are marked by the existence of several legal agreements created and maintained in distinct forums with the participation of different sets of actors (Table 1). The rules in the different regimes functionally overlap, yet there is no hierarchy for resolving conflicts between the agreements (Alter \& Meunier, 2009). Recall that the international institutions relevant to plant variety protection include the WTO, the UPOV and the United Nations (UN). ${ }^{25}$ According to Laurence Helfer, as international regime complexes evolve, countries from both the Global North and Global South engage in "regime shifting" (Helfer, 2004b). Helfer (2004a) defines regime shifting 'as an attempt to alter the status quo ante by moving treaty negotiations, law-making initiatives, or standard-setting activities from one international venue to another.' With regards to plant variety protection, Global North countries are increasingly moving vertically, from multilateral forums to regional or bilateral ones, while Global South countries respond by moving horizontally, from the WTO to the World Intellectual Property Organization (WIPO) or the UN institutions (Yu, 2007). The United States and EU bilateral agreements and investments which influenced Tanzania, Tunisia and Morocco's accession to the UPOV 1991 Convention discussed below is an example of vertical shifting. Nigeria's (and other Global South countries) text-based negotiations at WIPO for an international instrument to ensure the adequate protection of genetic resources and traditional knowledge is an example of horizontal shifting (WIPO-Intergovernmental Committee 2018). The expansion of regime complexes and the proliferation of regime-shifting have no doubt resulted in conflicting legal principles and systems covering plant varieties (Table 1). Notwithstanding, as Helfer (2009) points out, regime 
TABLE 1 The regime complex for plant variety protection

\begin{tabular}{|c|c|c|c|c|}
\hline & TRIPS & UPOV & CBD & ITPGRFA \\
\hline Dates & $\begin{array}{l}\text { Adopted: } \\
15 \text { Apr } 1994 \\
\text { Entered into force: } \\
1 \text { Jan } 1995\end{array}$ & $\begin{array}{l}\text { Adopted: } \\
2 \text { Dec } 1961 \\
\text { Entered into } \\
\text { force: } 10 \text { Aug } \\
1968 \text { Revised: } \\
10 \text { Nov 1972, } \\
23 \text { Oct 1978, } \\
\text { and } 19 \text { Mar } \\
1991\end{array}$ & $\begin{array}{l}\text { Adopted: } \\
5 \text { June } 1992 \\
\text { Entered into force: } \\
4 \text { June } 1993 \\
\text { Nagoya Protocol on } \\
\text { Access and Benefit } \\
\text { Sharing } \\
\text { Adopted: } \\
29 \text { Oct } 2010 \\
\text { Entered into force: } \\
12 \text { Oct } 2014\end{array}$ & $\begin{array}{l}\text { Adopted: } \\
3 \text { Nov } 2001 \\
\text { Entered into force: } \\
29 \text { June } 2004\end{array}$ \\
\hline Principal actors & $\begin{array}{l}\text { Global North (i.e. } \\
\text { United States, EU, } \\
\text { Canada, Japan) } \\
\text { Multinationals }\end{array}$ & $\begin{array}{l}\text { Global North } \\
\text { (i.e. Australia, } \\
\text { Canada, EU, } \\
\text { United States) } \\
\text { Seed industry }\end{array}$ & $\begin{array}{l}\text { Global South } \\
\text { (i.e. China, India, } \\
\text { G77, select African } \\
\text { countries) } \\
\text { CSOs (i.e. } \\
\text { Greenpeace, World } \\
\text { Wildlife Fund) }\end{array}$ & $\begin{array}{l}\text { Global South (i.e. Mexico, } \\
\text { India, select Latin American, } \\
\text { African and Caribbean } \\
\text { countries) } \\
\text { CSOs (i.e. La Via } \\
\text { Campesina, GRAIN, etc.) }\end{array}$ \\
\hline Regime objectives & $\begin{array}{l}\text { To promote and } \\
\text { enforce IPRs }\end{array}$ & $\begin{array}{l}\text { To grant and } \\
\text { protect } \\
\text { breeder's } \\
\text { rights }\end{array}$ & $\begin{array}{l}\text { To promote the } \\
\text { conservation and } \\
\text { sustainable use of } \\
\text { biological diversity; } \\
\text { fair and equitable } \\
\text { benefit sharing }\end{array}$ & $\begin{array}{l}\text { To promote the conservation } \\
\text { and sustainable use of } \\
\text { plant genetic resources for } \\
\text { food and agriculture; fair and } \\
\text { equitable benefit sharing in } \\
\text { harmony with the CBD }\end{array}$ \\
\hline Principles \& systems & $\begin{array}{l}\text { Patents, sui generis } \\
\text { system, combination } \\
\text { of systems }\end{array}$ & $\begin{array}{l}\text { Plant } \\
\text { breeder's } \\
\text { rights system }\end{array}$ & $\begin{array}{l}\text { Access and benefit } \\
\text { sharing principles }\end{array}$ & $\begin{array}{l}\text { Farmers' rights; } \\
\text { access and benefit sharing } \\
\text { principles }\end{array}$ \\
\hline $\begin{array}{l}\text { Entry into } \\
\text { force- Nigeria }\end{array}$ & 1 Jan 1995 & Not in force & $\begin{array}{l}\text { CBD- } 27 \text { Nov } 1994 \\
\text { Nagoya Protocol on } \\
\text { Access and Benefit } \\
\text { Sharing- Not in force }\end{array}$ & Not in force \\
\hline
\end{tabular}

Table 1 outlines four international treaties relevant to plant variety protection, namely TRIPS, UPOV, CBD and ITPGRFA, alongside their statuses in Nigeria.

Sources: Treaty texts, Rangnekar (2014) and the author's additional inputs.

complexes also provide greater leeway for states to interpret and implement treaties to further their national interests.

In interpreting and implementing Article 27.3(b) of TRIPS, Nigeria, like other WTO members, has three options. The first option is to design a patent system: exclusive patent rights over plant varieties for 20 years. The second option is to design a sui generis system: a unique system which could either be a UPOV-styled plant breeder's rights system or a creatively designed unique system which incorporates alternative principles such as farmers' rights as well as access and benefit sharing provisions set out in the ITPGRFA and the CBD. The third option is to have a combination of systems: a combination of a patent system and a sui generis system. Bearing in mind that the legal principles and systems set out in the CBD, ITPGRFA and UPOV shape or constrain the implementation of TRIPS, it is essential to highlight the status of these other treaties in Nigeria. Nigeria is a signatory to the CBD and ITPGRFA, but not UPOV. ${ }^{26}$ Its non-membership of UPOV means that Nigeria is not obliged to introduce the UPOV plant breeder's rights system. 
Regarding the options under Article 27.3(b) of TRIPS and concomitant international obligations as seen above, the sui generis option which incorporates farmers' rights, as well as access and benefit sharing principles, is best suited to Nigeria's socio-economic realities. The sui generis option provides the latitude for WTO members to construct any unique plant variety protection system that balances IPRs with relevant socio-political rights. Balancing IPRs with the reward and recognition principles set out in the CBD and ITPGRFA is vital in Nigeria for two reasons. First, the sui generis system will protect different stakeholders, including small-scale farmers and agribusinesses. Despite Nigeria's burgeoning agribusiness industry, about $80 \%$ of its farming population consists of small-scale farmers who conserve and improve plant genetic resources (Mgbenka \& Mbah, 2016). These small-scale farmers depend on traditional practices of saving, reusing, exchanging and selling farm-saved seeds for their livelihoods. Second, the sui generis system will provide access and benefit sharing principles. ${ }^{27}$ Despite Nigeria's rich biodiversity, it does not have operational access and benefit sharing legislation, as such, there are no official records of biological and genetic resources extracted from Nigeria (Nnadozie et al., 2003). Therefore, a sui generis system that incorporates farmers' rights, as well as access and benefit sharing principles is crucial to catering to the interests of the different stakeholders in Nigeria's agricultural sector. ${ }^{28}$

Although a sui generis system that incorporates CBD and ITPGRFA principles would be suited to Nigeria, external factors may constrain Global South WTO members' options under Article 27.3(b) TRIPS. For example, the UPOV Office undertakes extensive lobbying in the Global South through which it coerces these countries to adopt its plant breeder's rights system (GRAIN, 1998). In addition, Global North WTO members, especially the United States and EU increasingly coerce their Global South counterparts to accede to the UPOV 1991 Convention through bilateral or regional trade and investment agreements (Dutfield, 2011). ${ }^{29}$ The combination of these practices leads Global South WTO members, which are in a weaker bargaining position, to pick the UPOV system as their plant variety system of choice, despite their socio-economic realities.

To illustrate the point further, this article will now consider the choices made by certain African Group members in the WTO. ${ }^{30}$ Demonstrating clear understanding of the nuances and conflicting interests in plant variety protection systems, the Organization of African Union (now Africa Union) designed a sui generis guideline for African WTO members, titled African Model Legislation for the Protection of the Rights of Local Communities, Farmers and Breeders and for the Regulation of Access to Biological Resources (African Model Law) in 1998. According to Johnson Ekpere, the African Model Law was formulated inter alia to: (i) recognize, protect and support the rights of local communities, including farming communities, over their biological resources and plant varieties; and to (ii) recognize and protect the rights of breeders over varieties developed by them, in line with the needs and requirements of African states (Ekpere, 2003). ${ }^{31}$ The African Model Law expressly prohibited the patenting of plant varieties and rejected the indiscriminate adoption of the UPOV plant breeder's rights (Zerbe, 2005). Notwithstanding the African Model Law, five African countries: Kenya, Tanzania, Tunisia, Morocco and South Africa along with one regional intergovernmental organization: the African Intellectual Property Organization (OAPI), which has 17-member states, are party to UPOV. $^{32}$

OAPI was coerced to join UPOV through its strong affiliation with the French government and UPOV Office lobbies (Deere, 2009). Tanzania, Tunisia and Morocco signed bilateral trade or investment agreements that expressly mandated them to accede to the UPOV 1991 Convention. ${ }^{33}$ Indeed, these bilateral trade and investment agreements (or TRIPS-plus agreements) are more instrumental to IPRs reforms in the Global South than TRIPS (Campi \& Dueñas, 2017; Maskus \& Ridley, 2016). ${ }^{34}$ Two other regional intergovernmental organizations: the African Regional Intellectual Property Organization (ARIPO)-which has 19 members $^{35}$ and the Southern African Development Community (SADC)-which has 15 members $^{36}$ have also initiated the process of acceding to the UPOV 1991 Convention (Oguamanam, 2015; Strba, 2017). ${ }^{37}$ ARIPO and SADC's accession to UPOV would result in about $80 \%$ of African countries becoming UPOV members because 44 of the 54 African countries belong to OAPI, ARIPO and SADC. $^{38}$

It is important to set Nigeria in the context illustrated above. Nigeria does not have bilateral trade or investment agreements that expressly mandates it to accede to the UPOV 1991 Convention. Like Tanzania, as mentioned above, 
Nigeria is a member of the G8 New Alliance for Food Security and Nutrition (NAFSN), which promotes agriculture-led growth in Africa. ${ }^{39}$ However, unlike Tanzania, Nigeria did not expressly commit to acceding to the UPOV 1991 Convention under its NAFSAN cooperation framework. ${ }^{40}$ Instead, in Nigeria's cooperation framework, it generally commits to reforming its seed laws. ${ }^{41}$ Although Nigeria has signed other trade and investment agreements, some of which mention IPRs, none of the agreements mandates it to accede to the UPOV 1991 Convention. ${ }^{42}$

Nigeria is also not a party to any of the regional intergovernmental organizations: OAPI, ARIPO or SADC which have acceded to or expressed interest in acceding to the UPOV 1991 Convention. ${ }^{43}$ However, Nigeria has recently been in contact with the UPOV Office to request for assistance with designing its plant variety protection law based on the UPOV 1991 Convention (UPOV, 2017). ${ }^{44}$ It is difficult to ascertain Nigeria's reasons for contacting the UPOV office as no public explanations have been given. Regardless of its reasons, such assistance is likely to limit the opportunities for Nigeria to consider options other than the UPOV plant variety system. Dutfield (2011) explains that Global South countries often see UPOV membership as a way to attract foreign investment into their agriculture sectors. Recall that Nigeria is actively seeking foreign investment in this sector. ${ }^{45}$ Dutfield (2011) adds that UPOV deploys significant resources, through workshops and technical missions, to encourage and facilitate membership by countries that have expressed an interest in joining. It is therefore not surprising to observe that the UPOV records show that Nigerian participants have attended a variety of UPOV presentations, workshops and seminars. In 2017 alone, Nigerian participants attended five international presentations, workshops, seminars or lectures organized by or in collaboration with the UPOV Office. ${ }^{46}$ Dwijen Rangnekar observes that "these engagements with UPOV generate a socialization of policy makers, bureaucrats, and legislators which limit exploration of flexibility, ambiguity and space in Article 27.3(b) of TRIPS to stay in conformity with the UPOV plant breeder's rights system" (Rangnekar, 2013). One, therefore, expects to find Nigeria's options limited by the socialization that policy makers have been receiving; resulting in attempts to introduce a UPOV-styled plant variety system.

In line with the ethos of the African Model Law, this article argues that the UPOV system is unsuited to Nigeria's small-scale centered agricultural sector (African Model Law, 2000). The UPOV plant breeder's rights system expressly prohibits the inclusion of alternative conditions of protection or legal principles (Article 5 of the UPOV 1991 Convention). Article 5.1 of the UPOV 1991 Convention provides for breeder's rights over plant varieties that are "new, distinct, uniform and stable", ${ }^{47}$ while Article 5.2 expressly provides that "the grant of the breeder's rights shall not be subject to any further or other different conditions. . " ${ }^{48}$ In other words, accession to UPOV requires strict compliance with its plant breeder's rights system. The conditions of protection coupled with the prohibition of alternative conditions marginalize farmers' varieties, which are genetically variable, making it difficult to meet the distinct, uniform and stable conditions. ${ }^{49}$

Besides, according to Article 34.3 of the UPOV 1991 Convention, a national or regional instrument of accession may be deposited with the UPOV Office only if the UPOV Council approves the national or regional law as compliant with its prevailing Convention (Article 34.3 of the UPOV 1991 Convention). As such, even though alternative legal principles such as farmers' rights as well as access and benefit sharing are suited to a country like Nigeria, they cannot be incorporated in a UPOV-styled plant breeder's rights system, as they would contravene the provisions of the UPOV 1991 Convention. A counter-argument to this is that a country can design and introduce separate farmers' rights as well as access and benefit sharing laws. However, the value of having a comprehensive sui generis system is that it not only opens up opportunities for a WTO member state to reconcile conflicting pending obligations, it also allows it to balance stakeholders' competing interests (Ekpere, 2000). A comprehensive sui generis system embodies the interconnections between breeder's rights, farmers' rights, access and benefit sharing as well as biodiversity conservation which is invaluable to small-scale centered agricultural systems prevalent in the Global South (Oguamanam, 2015).

It is pertinent to point out that a WTO member can borrow provisions from the UPOV Convention, without joining UPOV. For example, both Thailand's Plant Variety Protection Act 1999 (PVPA, 1999) and India's Protection of Plant Varieties and Farmers Rights Act 2001 (PPVFRA, 2001) borrow plant breeder's rights provisions from the UPOV 1978 and 1991 Conventions. $^{50}$ The PVPA counterbalances the plant breeder's rights with the inclusion of farmers' 
rights to save and re-use seeds, community rights to protect existing varieties (local domestic plant varieties), as well as access and benefit sharing provisions from the ITPGRFA and CBD. Similarly, the PPVFRA counterbalances the plant breeder's rights with farmers' rights to save and re-use seeds, farmers' rights to protect farmers' varieties, as well as access and benefit sharing provisions from the ITPGRFA and CBD.

While the Thai and Indian examples indicate the possibility of introducing creatively designed sui generis systems by Global South WTO members, the implementation of the novel provisions in these systems is not without challenges. Pawarit Lertdhamtewe notes that despite the existence of provisions for the protection of local domestic varieties under Section 43 of the PVPA, no local domestic plant variety has been registered in Thailand (Lertdhamtewe, 2017). In fact, the mandated Ministerial Regulation required to set the rules and procedure for the registering local domestic plant varieties are yet to be adopted (Gagne \& Ratanasatien, 2016). ${ }^{51}$ On the other hand, Mrinalini Kochupillai notes that although farmers' varieties have been registered in India, the (distinct, uniform and stable) registration tests often require scientists to purify farmers' varieties further, and a large number of farmers' applications are unsuccessful, as scientists usually select only farmers' varieties with visible commercial potential (Kochupillai, 2016)..$^{52}$ In essence, the introduction of creatively designed sui generis systems does not always translate to practical implementation. Nonetheless, it is a step in the right direction.

Like the UPOV plant breeder's rights system, the patent option under TRIPS is not suited to Nigeria either. For one, TRIPS does not set out special provisions for patenting plant varieties. Article 27.1 of TRIPS provides patent protection for inventions in all fields of technology, provided the inventions are new, involve an inventive step and are capable of industrial application. However, Article 27.2 permits WTO members to exclude from patentability inventions which are necessary to protect ordre public or morality. Article 27.3 further permits WTO members to exclude from patentability "plants," "essentially biological processes for the production of plants" and "plant varieties." WTO members may prohibit patents for plant varieties, provided that they protect such varieties with an effective sui generis system (Helfer, 2004b). In providing for the patentability of plant varieties, TRIPS does not specify a particular form of patent system. WTO members can either include plant varieties within their existing utility patent laws or introduce a separate patent law for plant varieties. Recall that pre-TRIPS, the United States had a separate plant patent law in 1930, which protected only asexually reproduced plants, and through case law (such as Diamond $v$ Chakrabarty and J.E.M. Ag Supply v Pioneer Hi-Bred), ${ }^{53}$ it went on to extend utility patents to plants. Other WTO members that provide patents for plant varieties include Australia, Japan and New Zealand.

In general, patents for plant varieties provide rights that protect the patent owner and exclude others from exploiting the patented invention (Roffe, 2008). Article 28 of TRIPS provides that these rights include the rights to prevent third parties from making the product, using, offering for sale, selling or importing for those purposes the patented product or the product obtained directly by the patented process. In other words, the patent owner could obtain a patent on both the plant varieties and the process used to develop the plant varieties. The patents, which are often broadly worded, may restrict the use of both a new plant variety as well as individual components of such variety including DNA sequences, genes, cells, tissue cultures, seeds, specific plant parts, as well as the entire plant (Kloppenburg, 2004). The patent system poses challenges because it only provides narrow limitations on a patent owner's exclusive rights (Crucible Group, 1994; Dutfield, 2000). Article 30 of TRIPS permits WTO members to adopt limited exceptions to the exclusive rights conferred by a patent, provided the exceptions do not unreasonably conflict with the normal exploitation of the patent and do not unreasonably prejudice the legitimate interests of the patent owner, taking account of the legitimate interests of third parties. ${ }^{54}$ Considering that plant varieties are treated like inventions in other fields of technology, exceptions such as farmers rights to save, reuse, exchange and sell farm-saved seeds are often prohibited from patent systems because such exceptions unreasonably prejudice the legitimate interests of patent owners (Watal, 2000). Furthermore, patent owners reinforce the limitation on farmers' seed reuse and sale through contracts (Aoki, 2008). For example, in the case of Monsanto Co v McFarling, a farmer-Homan McFarling-signed a technology agreement with an authorized Monsanto dealer during the initial purchase of soybean seeds, promising not to replant seeds from the first generation of soybean crops and not to sell seeds produced by the first-generation crops to others. ${ }^{55}$ 
Although the subject matter and scope of protection under patent systems are more extensive than the UPOV plant breeder's rights system as seen above, neither patent systems nor the UPOV plant breeder's rights system prioritizes the interests of small-scale farmers who make up the bulk of the agricultural sectors in Global South countries like Nigeria (Crucible Group II, 2001). Small-scale farmers traditional practices such as saving, reusing and selling seeds, as well as benefit-sharing from the use of their abundant genetic resources and traditional knowledge are fundamental to agricultural production, employment and revenue in the Global South. For these reasons, the sui generis option under TRIPS which allows the incorporation of reward and recognition principles under the ITPGRFA and CBD, while safeguarding interests of different stakeholders in the agricultural sector is best suited to Nigeria. Without detracting from any of the above arguments promoting the introduction of a creatively designed sui generis system in Nigeria, it is important to point out that there is limited empirical evidence on the effects of plant variety protection systems in Global South countries (De Jonge 2014; Dutfield, 2008; Louwaars et al., 2005; UPOV, 2005). The limited empirical evidence is attributable to the different factors that affect the implementation of plant variety protection systems, including competing national laws, policies and practices alongside social, economic and political contexts.

\section{PLANT VARIETY PROTECTION LANDSCAPE IN NIGERIA: CURRENT POSITION OF THE LAW, IP REFORM ATTEMPTS AND RECENT DEVELOPMENTS}

Parts I and II have discussed reasons why Nigeria should introduce a plant variety protection system and argued for the type of system best suited to it. Part III now turns to the current plant variety protection landscape in Nigeria. That is, the position of the law, attempts to introduce plant variety protection, as well as recent developments. This analysis gives an understanding of how Nigeria currently regulates plant varieties, in order to provide insights into avenues for law and policy developments.

IPRs systems were introduced in Nigeria during the colonial era, as was the case for some former sub-Saharan British colonies such as Ghana and Kenya (Adewopo, 2012a; Bentley, 2011; Okediji, 2003). Similar to Ghana and Kenya, the IPRs systems introduced in Nigeria excluded plant variety protection, which is unsurprising because IPRs were not extended to plant varieties in Britain until 1964, four years after Nigeria had gained its independence. ${ }^{56}$ From independence until now, Nigeria has maintained its plant variety protection system status quo. Section 1.4(a) of its Patents and Designs Act (1970), which was the first post-independent patent system prohibits patents for plant or animal varieties. Despite the prohibition, Nigeria fails to fulfil its obligations under Article 27.3(b) of TRIPS through a sui generis system. However, Nigeria has two non-IPRs laws (Table 2) that regulate the registration, release and commercialization of plant varieties, namely the National Crop Varieties and Livestock Breeds (Registration, etc.) Act 1987 (NCVLBA, 1987) and the National Agricultural Seed Act 1992 (NASA, 1992). ${ }^{57}$

TABLE 2 Legal architecture for plant varieties-Nigeria

\begin{tabular}{ll}
\hline Laws and regulation & Coverage \\
\hline Patents and Designs Act 1970 & Prohibition of patents for plant varieties \\
\hline $\begin{array}{l}\text { National Crop Varieties and Livestock Breeds } \\
\text { (Registration, etc.) Act } 1987\end{array}$ & Registration of plant varieties \\
\hline National Agricultural Seed Act 1992 & \\
\hline $\begin{array}{l}\text { National Environmental (Access to Genetic Resources } \\
\text { and Benefit Sharing) Regulation } 2009\end{array}$ & Commercialization of plant varieties \\
\hline
\end{tabular}

Table 2 outlines the laws and regulation relevant to plant varieties in Nigeria.

Source: the author. 
The NCVLBA sets out the procedure for registering new varieties in Nigeria. Sections 2 and 8 of the NCVLBA provide that the registration and written authorization of the Registrar of the National Centre for Genetic Resources and Biotechnology (NACGRAB) ${ }^{58}$ is a prerequisite for the release of new varieties in Nigeria. Naming or releasing crop varieties in Nigeria without the written authority of the Registrar of the National Register for Crop Varieties and Livestock Breeds is an offence. ${ }^{59}$ Before a crop variety is registered or released in Nigeria, it has to meet the UPOVstyled distinct, uniform and stable conditions for protection as set out in the 2016 Guidelines for Variety Registration and Release of New Crop Varieties in Nigeria (NACGRAB Guidelines) (NACGRAB, 2016b). ${ }^{60}$ Under the NACGRAB Guidelines, a variety is distinct if it is clearly distinguishable from any other existing variety in Nigeria. It is uniform if individual plants of new varieties remain sufficiently uniform at the same growth stages in the expression of their characteristic. It is stable if the genetic traits of the new variety remain stable through generations. There are no limitations or exceptions to these conditions for protection, as such, they constitute a legal barrier to release and registration of farmers' varieties which do not meet these conditions. More directly, the NACGRAB Guidelines expressly exclude small-scale farmers from its list of actors qualified to develop new varieties for registration and release in Nigeria. ${ }^{61}$ Only National Agricultural Research Institutes in Nigeria, universities in Nigeria, the Consultative Group on International Agricultural Research Centres, private seed companies and non-governmental organizations registered in Nigeria can release new crop varieties. ${ }^{62}$

The NASA regulates the commercialization of seeds in Nigeria. Section 22 of NASA provides for formal registration as a condition for producing, processing and marketing seeds for commercial purposes in Nigeria. Only registered seed production companies, seed enterprises on contract for seed companies, breeder seed production agencies, foundation seed growers, enterprise seed processors and seed dealers are licensed to produce and market seeds commercially in Nigeria. ${ }^{63}$ Other than those registered, no one-such as a small-scale farmer-is permitted to produce, process or market seeds for commercial purposes. That is, NASA prohibits small-scale farmers from selling their farmers' varieties except they are classified and registered as persons and organizations licensed to engage in seed production and marketing mentioned above. ${ }^{64}$ However, under Section 22.2 of NASA, the prohibition does not apply to anyone growing and delivering seeds directly to others without monetary consideration, or to the noncommercial sowing of seeds on personal farms. In other words, while unregistered small-scale farmers are prohibited from producing, processing or marketing seeds for commercial purposes, they are not precluded from engaging in barter and other non-commercial exchanges.

Jointly, the provisions of the NCVLBA and the NASA marginalize small-scale farmers by excluding the release, registration and commercialization of farmers' varieties. These laws along with the NACGRAB Guidelines borrow from the UPOV model. Although the NCVLBA and NASA are not IPRs systems as required under Article 27.3(b) of TRIPS (Leskien \& Flitner, 1997), they assume importance in this discussion because they may undermine farmers' rights provisions in a sui generis plant variety protection system introduced in Nigeria.

Similar to its position on plant variety protection, Nigeria does not currently have farmers' rights as per provisions of the ITPGRFA or CBD. The absence of farmers' rights provisions in Nigeria may be linked to the absence of plant breeder's rights. As discussed in Part II, since farmers' rights seek to counter-balance plant breeder's rights, there is no pressing need for farmers' rights in Nigeria because it does not have a plant breeder's rights system. However, as noted in the preceding paragraph, provisions in the NCVLBA and NASA restrict small-scale farmers from releasing, registering and commercializing farmers' varieties. Therefore, while plant breeder's rights do not restrict farmers' rights, farmers' rights are restricted through non-IPRs laws. As such, in thinking about designing a creative sui generis system to protect interests of both small-scale farmers and agribusinesses, it is important to pay attention to both relevant IPRs as well as non-IPRs laws.

Conversely, Nigeria has an access and benefit sharing regulation titled the National Environmental (Access to Genetic Resources and Benefit Sharing) Regulation 2009 (National Environmental Regulation, 2009) as per provisions of the CBD (Table 2). However, the National Environmental Regulation, prepared by the National Environmental Standards and Regulation Agency (NESREA) is not operational because the Federal Ministry of Environment (FME) rejects it. FME officials assert that the FME rejects the National Environmental Regulation because NESREA went 
beyond its powers in drafting it (Fieldwork interview with FME official, 2015). Therefore, Nigeria does not have operational farmers' rights or access and benefit sharing provisions either as distinct legal frameworks or as part of a plant variety protection system.

In the absence of a plant variety protection system, Nigeria has a home-grown system that protects only private breeders' research and investment. New varieties bred and released by public research institutions are considered public goods, which are open for everyone to use while new varieties bred and released by private companies are protected with a moratorium for ten years (Fieldwork interview with Crop Variety Release Committee of Nigeria (CVRCN) members, 2015). Private companies are granted the moratorium for a ten-year period to market the new varieties, after which the varieties enter into the public domain. Although the moratorium is similar to IPRs systems, it is not an IPRs system because it is not entrenched in any national IPRs legislation. As such, the moratorium remains unenforceable in court.

While there have been attempts to introduce a plant variety protection system in Nigeria, these attempts have been free from accompanying public debates and protests typical in other Global South countries such as Thailand and India, or more recently, in Ghana (APBREBES, 2014; Food Sovereignty Ghana, 2013; Kanniah, 2005; Lertdhamtewe, 2017; Ramanna \& Smale, 2004). ${ }^{65}$ From the 1980s, even before TRIPS entered into force, there have been IPRs reform attempts in Nigeria, including attempts to introduce a plant variety protection system (Adewopo, 2012b; Sodipo, 1994). At the time, Nigeria had three IP laws: The Trademark Act (1965), the Patents and Designs Act 1970 and the Copyrights Act (1970). The Copyright Act has been amended three times: in 1988, 1992 and 1999, but attempts to amend the Trademark Act, as well as the Patents and Designs Act, have both been unsuccessful.

Two reasons for the unsuccessful Trademark and Patent reforms are lack of political will of the Nigerian Government to prioritize industrial property and lack of interested actors to advocate for the reforms. Although a draft Industrial Property Commission (IPCOM) Bill which sought to consolidate trademark, patent and design laws into a single industrial property law was produced in 1991, it was not passed. The Nigerian Intellectual Property Commission (NIPCOM) Bill of 2006 further attempted to introduce a consolidated IP law. Going beyond the IPCOM Bill, the NIPCOM Bill harmonized all IP laws including copyrights. The NIPCOM Bill also incorporated a section on plant varieties, animal breeders' and farmers' rights. In essence, the NIPCOM Bill covered the broadest scope of IPRs subject matter in the history of IP law in Nigeria. It harmonized copyrights and industrial property and introduced sui generis rights. However, the NIPCOM Bill was not passed into law. Further IPRs reform attempts including the Intellectual Property Commission Bill 2008 (2008 IPCOM) were also unsuccessful (Nwokocha, 2012).

While the Nigerian Government has demonstrated a lack of appreciation and prioritization of IPRs related issues, non-state actors in the patent, trademark and plant variety protection related industries have also failed to promote industrial property reforms actively. Non-state actors have been at the forefront of actively lobbying for copyright reforms; the book publishing industry and the Performing Musicians Associations of Nigeria (PMAN) primarily drove the three copyright reforms (Adewopo, 2012a). In fact, the first copyright amendment in 1988 was passed two weeks after a nationwide protest organized by PMAN (Sodipo, 1994). Recall also that the sui generis plant variety protection systems in Thailand and India discussed in Part II was thanks to the interventions of vibrant CSOs, such as BIOTHAI in Thailand and Gene Campaign in India (Kuanpoth, 2009; Lianchamroon, 1998; Plahe, 2011; Ramanna, 2006). However, Nigeria does not have equivalent vibrant CSOs propelling patent, trademark or plant variety protection reforms.

Despite the absence of vibrant CSO activism and public debates or participation, Nigeria currently has an Industrial Property Commission Bill (IPC) undergoing legislative process at its National Assembly. ${ }^{66}$ The IPC Bill, introduced in 2016 by Hon. Chime Oji Agu is now at the Committee Stage in Nigeria's House of Representatives. ${ }^{67}$ The First Reading of the IPC Bill was on 08 June 2016, and the Second Reading on 18 January 2017. The Bill was thereafter referred to the Commerce Committee for further consideration. The Committee Stage is crucial as it allows public hearing and participation, providing room for fundamental changes to the Bill, including recommendations to alter, amend, rewrite or block the Bill. However, considering the silence in the industrial property reform process as mentioned above, it remains to be seen what Hon. Agu would present at the next stage of the Bill, which is the Third Reading where he conveys conclusions from the Committee Stage. 
In its current form, the IPC Bill, like its predecessors, seeks to harmonize industrial property laws in Nigeria. It sets out patent and designs, trademark and plant variety protection provisions in one industrial property law. Also similar to previous IP Bills, the plant variety protection provisions in the IPC Bill were drawn from the African Model Law. Incidentally, Johnson Ekpere, the chief protagonist of the African Model Law who is Nigerian, contributed to the design of the plant variety protection system when it was initially introduced in the NIPCOM Bill in $2006 .{ }^{68}$ Subsequent IP Bills directly transplanted the plant variety protection provisions in the NIPCOM Bill, albeit with some noteworthy alterations in the case of the IPC Bill.

Sections 171-187 of the IPC Bill which covers plant variety protection provides for the protection of new varieties, extant varieties and farmers' varieties. ${ }^{69}$ The conditions for protection set out in the IPC Bill contradict the NACGRAB Guidelines. Recall that the NACGRAB (2016a) Guidelines provide that only new varieties that meet the distinct, uniform and stable conditions are eligible for protection. In contrast, Section 173 of the IPC Bill provides that farmers can register varieties with specific attributes identified by the farmer or farming community which do not have to meet the distinct, uniform and stable conditions. Section 177 (d) of the IPC Bill also expressly allows farmers, group of farmers or farming communities to apply for registration of varieties, unlike the NCVLBA, NASA and NACGRAB Guidelines which exclude these important groups of stakeholders in Nigeria's agriculture sector.

One question that arises from this contradiction is-if the IPC Bill is passed in its current form, would it trump the NCVLBA and NASA? In other words, would farmers and farming communities benefit from the provisions of the IPC Bill which allow for the protection of farmers varieties and extant varieties, despite the framework for release, registration and commercialization of new varieties instituted by the NCVLBA and NASA ${ }^{70}$ The preceding question is for the Nigerian judiciary to answer, as IP and non-IP laws do not have an established hierarchy. Therefore, conflicts between them would be resolved by the interpretative prism of the courts. The existence of conflicting laws is bound to create confusion about the regulation of plant varieties, especially as the NCVLBA and NASA have an established practice for registration and commercialization over the years. ${ }^{71}$ As the IPC Bill is still at the Committee Stage, the legislative arm of government can pre-empt future legal tussles by clarifying the position on the law on release, registration and commercialization of plant varieties, alongside plant variety protection in Nigeria.

Further concerns with the IPC Bill stem from the exceptions excluded. Unlike its other predecessors, the IPC Bill excludes specific significant provisions favorable to small-scale farmers and public interests which are essential elements of the African Model Law. ${ }^{72}$ First, the 2016 IPC Bill fails to provide farmers' rights to save, use, exchange and sell farm-saved seed or propagating materials of farmers' varieties, as well farmers' rights to save use, multiply and process farm-saved seed of protected varieties which were in the previous IPRs Bills. ${ }^{73}$ As highlighted above, farmers' rights provisions are important to protect the traditional farming practices and livelihoods of small-scale farmers in Nigeria. Second, the 2016 IPC Bill excludes private use (acts done privately and on a non-commercial scale), as well as research (scientific research, experiments and teaching) exceptions to breeder's rights which were set out in the previous IPRs Bills. ${ }^{74}$ Plant breeders have unfettered exclusive rights to produce, sell, market, distribute, import or export registered varieties. ${ }^{75}$ The private use and research exception provisions are important not only to protect small-scale farming practices but also to promote research in Nigeria. Third, the IPC Bill excludes provisions allowing government use of protected varieties and grant of compulsory licenses when it is in the public interest to do so. ${ }^{76}$ Government use of protected varieties and grant of compulsory licenses are imperative to protect the overall interests of Nigerians including food security, nutrition, health and biological diversity whenever necessary.

The IPC Bill is antithetical to small-scale farmers' and overall public interests. Therefore, the National Assembly should not pass it in its current form. Although the IPC Bill seeks to reform IP laws in Nigeria in line with commercial developments while simultaneously attempting to fulfil pending international obligations, the plant variety protection provisions currently set out in the Bill are skewed in favor of agribusinesses. The exclusion of farmers' rights, government use and compulsory license provisions in the IPC Bill may be subtly steering Nigeria the UPOV way. A plausible explanation for a UPOV-styled plant variety protection system is the ongoing UPOV socialization in Nigeria as mentioned in Part II. However, the IPC Bill is not fully UPOV-compliant because it provides for the protection of extant and farmers' varieties, which are outside the class of protection allowed under UPOV. ${ }^{77}$ This article proposes a 
creative sui generis system which incorporates farmers' rights as well as access and benefit sharing as best suited to Nigeria.

Consequently, it is recommended that the farmers' rights provisions, government use and compulsory license provisions that were in sections 188-208 of the 2008 IPCOM Bill be re-incorporated into the IPC Bill. It is further suggested that benefit sharing provisions in line with the CBD and its Nagoya Protocol be incorporated into the IPC Bill. Benefit sharing provisions are not comprehensively addressed in both the IPC Bill and previous IP Bills. The African Model Law, the PVPA and the PPVFRA can provide guidelines on benefit sharing. Significantly, it is imperative that the coverage of the law, conditions for protection and scope of protection of any plant variety protection system introduced in Nigeria be tailored to suit its socio-economic realities. The overall goal of this plant variety protection system should be to achieve and maintain a balance between farmers' rights, farming community rights and plant breeder's rights while providing for access and benefit sharing.

Achieving and maintaining this balance as well as clarity on the overarching legal structure for the release, registration, commercialization and plant variety protection is indeed an arduous task, requiring a multidisciplinary team. The multidisciplinary team could include: (i) IP specialists; (ii) academics from law, social sciences and life sciences; (iii) government officials from the relevant ministries, including agriculture, environment, trade, justice, science and technology; (iv) small-scale farmers'; (v) farming communities; and (vi) plant breeders. The IP specialists, academics and government officials would be responsible for coordinating and creatively drafting the law in line with national realities, suitable international standards and Nigeria's pending international obligations. The small-scale farmers' and farming community's representatives would explain how they conserve and develop plant varieties, as well as their opinions about farmers' rights, access and benefit sharing as well as IPRs for plant varieties which would provide first-hand insights on how to conceptualize these issues in the Bill. The plant breeders would explain the formal process of sourcing and developing new plant varieties which would also provide first-hand insights on how to conceptualize access and benefit sharing as well as breeder's rights in the Bill. With the rigorously researched plant variety protection system proposed, Nigeria could join the league of Global South WTO members with creatively designed sui generis plant variety protection systems, such as Thailand and India.

The proposed plant variety protection system would further demonstrate that Global South WTO members can translate their rhetoric at the TRIPS Council into domestic legal architecture (WTO Joint Communication from the African Group IP/C/W/404). In other words, the proposed Nigerian example, along with the African Model Law, the PVPA and the PPVFRA, show that Global South WTO members understand the complexities underlying plant variety protection debates, and they can successfully design systems suited to their interests while remaining within the boundaries of international obligations. This way, Nigeria's plant variety protection law-making and law would provide valuable examples for other Global South WTO members.

\section{5 | CONCLUSION}

This article has explored the importance of introducing a plant variety protection system in Nigeria. Nigeria's evolving agricultural sector, susceptibility to external pressure and pending international obligations are three reasons for it to introduce a plant variety protection system. Although this article calls for Nigeria to proactively introduce a sui generis system suited to its national realities, this call is extended to other Global South WTO members that are yet to fulfil their obligations under Article 27.3(b) of TRIPS. The sui generis option opens up the avenue for Global South WTO members to creatively recognize farmers' rights and breeder's rights while ensuring access and benefit sharing.

Designing this system would require careful and rigorous law-making. TRIPS does not define sui generis; therefore, law and policy makers in Nigeria would have to creatively design the proposed system. Nigeria has a draft IPC Bill, which sets out plant variety protection provisions modeled after the African Model Law. However, the IPC Bill omits specific significant provisions from the African Model Law, including farmers' rights as well as access and benefit sharing principles, which this article argues are fundamental components of a sui generis plant variety protection 
system suited to Nigeria. This article has suggested the establishment of a dedicated multidisciplinary team to design an exemplary and beneficial plant variety protection system for Nigeria. To achieve this, it is also important to revisit existing non-IPRs laws regulating plant varieties-the NCVLBA and the NASA to ensure they do not undermine provisions of the proposed sui generis plant variety protection system.

The future legal control of plant varieties is crucial to Nigeria's food security and food sovereignty. Despite African countries' move toward UPOV plant breeder's rights system, the introduction of a creatively designed sui generis system in Nigeria can serve as an alternative guide for the continent. It is hoped that this timely article will prompt the suggested actions and reactions.

\section{ABOUT THE AUTHOR}

Titilayo Adebola, LLM (University of Warwick), PhD (University of Warwick). Tutor, Global Intellectual Property Law and Policy, School of Law, the University of Warwick; emal: titilayoadebola@gmail.com

\section{ACKNOWLEDGMENTS}

This article builds on the author's doctoral thesis submitted to the University of Warwick. The author would like to thank Professor Graham Dutfield, Dr. Ben Farrand, Dr. Bolanle Adebola and the two anonymous reviewers for their valuable comments on earlier drafts of the article.

\section{ENDNOTES}

${ }^{1}$ The definition of plant varieties adopted in this article is the legal definition set out in Article 1 of the UPOV 1991 Convention. Article 1 of the UPOV 1991 Convention provides that plant varieties are a plant grouping within a single botanical taxon of the lowest rank, which grouping, irrespective of whether the conditions for the grant of a breeder's right are fully met, can be: (i) defined by the expression of the characteristics resulting from a given genotype or combination of genotypes; (ii) distinguished from any other plant grouping by the expression of at least one of the said characteristics; and (iii) considered as unity with regard to its suitability for being propagated and unchanged. The terms "plant varieties" and "seeds" are used interchangeably in this article.

${ }^{2}$ According to the National Centre for Genetic Resources and Biotechnology (NACGRAB) Variety Release Catalogue, 608 new plant varieties have been released in Nigeria from 1984 to 2016. http://www.nacgrab.gov.ng/images/ Varieties_Released_Catalogue.pdf accessed 28 November 2017.

${ }^{3}$ Agreement on Trade Related Aspects of Intellectual Property Rights (1994) Annex 1C, 33 ILM 81.

${ }^{4}$ During the TRIPS negotiations in the late 1980s and early 1990s, Nigeria was under military dictatorships, which were not concerned about fulfilling international obligations. While other developing country WTO members like India and Thailand were designing plant variety protection systems in the late 1990s, Nigeria was experiencing political instability. Furthermore, both agribusinesses and CSOs involved in circulating ideas and promoting the introduction of plant variety protection in other WTO member states were silent in Nigeria at the time.

${ }^{5}$ This conceptualization of agribusinesses differs from the original definition coined by John Davis and Ray Goldberg in the late 1950s. Davis and Goldberg defined agribusinesses as the sum total of all operations involved in the manufacturing, processing and distribution of agricultural commodities. See Davis and Goldberg (1957) A Concept of Agribusiness (Harvard University, Boston).

${ }^{6}$ The Organization of Petroleum Exporting Countries members (including Nigeria) earned about $\$ 433$ billion in net oil revenues in 2016, which was the lowest since 2004 . The 2016 revenue represents a $15 \%$ decline from $\$ 509$ billion earned in 2015. US Energy Information Administration-https://www.eia.gov/todayinenergy/detail.php?id=31292 accessed 28 November 2017.

${ }^{7}$ Since Nigeria's independence in 1960, successive administrations have introduced a variety of agricultural policies. Examples of the policies, plans and programmes introduced include the National Accelerated Food Production Programme 1972, Agricultural Development Projects 1974, Operation Feed the Nation 1976, River Basin Development Authorities 1976, Green Revolution Programme 1980, Family Support Programme 1994, Family Economic Advancement Programme 
1996, National Economic Empowerment and Development Strategy 1999, as well as National Special Programme on Food Security 2002.

${ }^{8}$ Other core achievements of the ATA were the introduction of the Nigerian Incentive Based Sharing of Agricultural Lending (NIRSAL), the Staple Crops Processing Zones (SCPZs) and the Agricultural Resilience in Nigeria (ARN). NIRSAL developed by the Central Bank of Nigeria in partnership with the Alliance for a Green Revolution in Africa aimed to increase farmers' access to credit by de-risking agricultural financing by banks. SCPZs focused on encouraging different regions of the country produce crops in which they enjoy a comparative advantage and to build commodity value chains around them. ARN focused on reducing food and nutrition vulnerability.

9 TRIPS is part of the WTO set of agreements. WTO members cannot "cherry-pick." WTO membership requires signing all of its agreements including agreements on trade in goods, services and TRIPS.

${ }^{10}$ Article 65 of TRIPS.

${ }^{11}$ The Nigerian delegation at the TRIPS Council has addressed questions about plant variety protection in Nigeria. For example, at the TRIPS Council meeting from 5 to 7 March 2002, the Nigerian delegation explained that Nigeria did not have a plant variety protection system because it had only recently (in May 1999) transitioned from military rule to a civilian administration. The delegation further explained that the military rulers did not pay much attention to fulfilling international obligations. WTO Council for TRIPS, Review of Legislation on 5-7 March 2002 (8 June 2004) IP/Q/NGA/1, IP/Q2/NGA/1, IP/Q3/NGA/1, IP/Q4/NGA/1, 2-3.

${ }^{12}$ Within Africa, only Kenya, South Africa and Zimbabwe had plant variety protection systems before TRIPS. Kenya's first IPRs provisions on plant varieties was the Seeds and Plant Varieties Act 1972, South Africa had the Plant Breeder's Rights Act 1976, while Zimbabwe had the Plant Breeder's Rights Act 1973.

${ }^{13}$ One of the reasons for the introduction of the UPOV Plant Breeder's Rights system was to harmonize the different European systems. On the history of UPOV, see also UPOV. (1991). Seminar on the Nature of and Rationale for the Protection of Plant Varieties under the UPOV Convention. UPOV Publication No 697 (E).

14 Sidney A Diamond, Commissioner of Patents and Trademarks v Ananda M Chakrabarty et al. (Diamond et al.,1980) 447 US 303.

${ }^{15}$ While the US Plant Patent Act 1930 protected asexually reproduced plant varieties excluding tuber propagated plants, the United States had also introduced the Plant Variety Protection Act in 1970 to protect sexually reproduced and tuber propagated plant varieties before the 1980 Diamond v Chakrabarty case. Ex Parte Hibberd and J E M Ag Supply v Pioneer HiBred further confirmed the patentability of plant varieties in the United States. (see: Ex Parte Hibberd et al. (1985) 227 USPQ 443; JEM AG Supply Inc, DBA Farm Advantage Inc et al. v Pioneer Hi-bred International Inc (JEM, 2001) 534 US 124.

16 The genetic resources used in developing new plant varieties.

${ }^{17}$ Farmers' rights are also set out in Article 9 of the ITPGRFA.

${ }^{18}$ CBD (1992) 1760 UNTS 143, 21 ILM 818.

${ }^{19}$ For a comprehensive history of farmers' rights, see: Regine Andersen, Historical Context: Evolving International Cooperation on Crop Genetic Resources' in Michael Halewood (ed) Farmers' Crop Varieties and Farmers Rights: Challenges in Taxonomy and Law (Routledge 2016) 99-128 and Regine Andersen, 'Farmers Rights: Evolution of the International Policy Debate and National Implementation' in Michael Halewood (ed) Farmers' Crop Varieties and Farmers Rights: Challenges in Taxonomy and Law (Routledge 2016) 129-152. See also Farmers' Rights: Resource Pages for Decision-Makers and Practitioners http://www.farmersrights.org/

${ }^{20}$ FAO of the UN Resolution 5/89 (1989) and Resolution 3/91 (1991), Annex to the IU on Plant Genetic Resources. FAO Resolution 5/89: Farmers' rights means rights arising from the past, present and future contributions of farmers in conserving, improving and making available plant genetic resources, particularly those in the International Community, as trustee for present and future generations of farmers. FAO Resolution 3/91: Nations have sovereign rights over their plant genetic resources.

21 ITPGRFA (2001) Res 3/2003 FAO Conference.

22 Emphasis added.

${ }^{23}$ Unlike the patent system and the UPOV plant breeder's rights systems, only a few Global South WTO members such as India have introduced farmers' rights. As such, while activists and Global South actors pushed for a legally binding treaty on farmers' rights, the treaty has not resulted in the widespread changes to plant variety protection systems anticipated.

${ }^{24}$ The CBD refers to "biological resources," rather than "genetic resources," used in the ITPGRFA. The definitions of both terms in the CBD and ITPGRFA reveal that "biological resources" is wider and even encompasses "genetic resources." Article 2 of the CBD defines "biological resources" as genetic resources, organisms or parts thereof, populations, or any other biotic component of ecosystems with actual or potential use or value for humanity. On the other hand, Article 2 of the ITPGRFA defines "plant genetic resources for food and agriculture" as any genetic material of plant origin of actual or 
potential value for food and agriculture, and "genetic material" as any material of plant origin, including reproductive and vegetative propagating material, containing functional units of heredity.

25 There are also negotiations for a genetic resources treaty at the WIPO's Intergovernmental Committee on Intellectual Property and Genetic Resources, Traditional Knowledge and Folklore (IGC). See generally: WIPO, "Intergovernmental Committee" http://www.wipo.int/tk/en/igc/ accessed 28 November 2017.

${ }^{26}$ However, Nigeria is yet to ratify the ITPGRFA.

${ }^{27}$ Nigeria is rich in biodiversity; it is endowed with a variety of plant and animal species due to its strategic topography which spans different climatic and ecological zones (Nigeria-CBD Biodiversity Report, 2015). On access and benefit sharing legislation in Nigeria, see discussion on the National Environmental (Access to Genetic Resources and Benefit Sharing) Regulation 2009 in part III.

${ }^{28}$ As farmers' rights is a vague principle in the ITPGRFA as mentioned above, Nigeria would have to clarify how it seeks to define and conceptualize it.

${ }^{29}$ See also discussion on vertical regime shifting above (Yu, 2007).

${ }^{30}$ A number of countries in the WTO formed coalitions to speak with one voice, using a single negotiating team. The African Group is one of such regional groups, it consists of all African WTO members, namely: Angola, Benin, Botswana, Burkina Faso, Burundi, Cameroon, Central African Republic, Chad, Congo, Cote d'Ivoire, Djibouti, Egypt, Gabon, the Gambia, Ghana, Guinea, Guinea Bissau, Kenya, Lesotho, Madagascar, Malawi, Mali, Mauritania, Mauritius, Morocco, Mozambique, Namibia, Niger, Nigeria, Rwanda, Senegal, Sierra Leone, South Africa, Swaziland, Tanzania, Togo, Tunisia, Uganda, Zambia and Zimbabwe.

${ }^{31}$ Professor Johnson Ekpere was the Executive Secretary of the OAU's Scientific, Technical and Research Commission (STRC) at the time of the development of the African Model Law. Ekpere was actively involved in designing and promoting the Law. As Chidi Oguamanam notes, Ekpere is the "intellectual brainchild" of the African Model Law (Oguamanam, 2015).

32 OAPI's 17 members are Benin, Burkina Faso, Cameroon, Central African Republic, Chad, Comoros, Congo, Ivory Coast, Equatorial Guinea, Gabon, Guinea, Guinea-Bissau, Mali, Mauritania, Niger, Senegal and Togo.

${ }^{33}$ Euro-Mediterranean Agreement establishing an association between the European Communities and their Member States, of the one part and the Kingdom of Morocco, of the other part (19 March 2000) OJEC L70/2, Annex 7, art 1 http://trade.ec. europa.eu/doclib/docs/2006/march/tradoc_127906.pdf accessed 28 November 2017; Tanzania: "G8's New Alliance for Food Security and Nutrition in Tanzania" https://www.usaid.gov/sites/default/files/documents/1868/ TanzaniaCooperationFramework.pdf accessed 28 November 2017, Tunisia: "Council and Commission Decision of the Council and the Commission of 26 January 1998, on the conclusion of a Euro-Mediterranean Agreement establishing an association between the European Communities and their Member States, of the one part, and the Republic of Tunisia, of the other part" (98/238/EC, ECSC, 30 March 1998) OJ L 97/1, Annex 7 http://eur-lex.europa.eu/legal-content/EN/TXT/ PDF/?uri=CELEX:31998D0238\&from=EN accessed 28 November 2017; Kenya and South Africa have vibrant seed industries, which pushed for the establishment of plant variety protection systems before TRIPS entered into force. See note 11 above.

34 On the global increase in IPRs systems for plant varieties, see Campi \& Nuvolari (2015). Intellectual property protection in plant varieties. A worldwide index (1961-2011), Research Policy 44 (4), 951-964.

${ }^{35}$ ARIPO's 19 members are: Botswana, Gambia, Ghana, Kenya, Lesotho, Liberia, Malawi, Mozambique, Namibia, Rwanda, Sao Tome and Principe, Sierra Leone, Somalia, Sudan, Swaziland, Uganda, United Republic of Tanzania, Zambia and Zimbabwe.

${ }^{36}$ SADC's 15 members: Angola, Botswana, the Democratic Republic of the Congo, Lesotho, Madagascar, Malawi, Mauritius, Mozambique, Namibia, Seychelles, South Africa, Swaziland, United Republic of Tanzania, Zambia and Zimbabwe.

${ }^{37}$ In UPOV's Status in Relation to the International Union for the Protection of New Varieties of Plants (UPOV) as of 10 October 2017, ARIPO is listed under "States and intergovernmental organizations which have initiated the procedure for acceding to the UPOV Convention" and SADC is listed under "States and intergovernmental organizations that have been in contact with the Office of the Union for assistance in the development of laws based on the UPOV Convention." Retrieved from http://www.upov.int/export/sites/upov/members/en/pdf/status.pdf

38 Some African countries belong to more than one regional organization.

${ }^{39}$ NAFSN has 10 African partner countries, namely: Benin, Burkina Faso, Cote d'Ivoire, Ethiopia, Ghana, Malawi, Mozambique, Nigeria, Senegal and Tanzania.

40 The Federal Republic of Nigeria, "Cooperation Framework to Support the New Alliance for Food Security \& Nutrition in Nigeria" https://new-alliance.org/sites/default/files/resources/new-alliance-progress-report-coop-framework-nigeria_ compressed.pdf accessed 28 November 2017. 
${ }^{41}$ Nigeria's framework policy action on seeds states that it will pass and implement seed law that reflects the role of the private sector in technology development, seed multiplication and marketing and reflecting the regulatory role of the public sector, consistent with ECOWAS seed law.

${ }^{42}$ See generally: UNCTAD Investment Policy Hub, Nigeria' http://investmentpolicyhub.unctad.org/IIA/CountryBits/ 153\#iialnnerMenu accessed 28 November 2017; The World Bank, Global Preferential Trade Agreements Database https://wits.worldbank.org/gptad/trade_database.html accessed 28 November 2017; WTO, Preferential Trade Agreements, http://ptadb.wto.org/SearchByCountry.aspx accessed 28 November 2017; WTO, Regional Trade Agreements Information System (RTA-IS)http://rtais.wto.org/UI/PublicMaintainRTAHome.aspx accessed 28 November 2017.

43 Nigeria has maintained its observer status in ARIPO.

${ }^{44}$ Status in Relation to the International Union for the Protection of New Varieties of Plants (UPOV) as of 10 October 2017, States and intergovernmental organizations which have been in contact with the Office of the Union for assistance in the development of laws based on the UPOV Convention. http://www.upov.int/edocs/pubdocs/en/upov_pub_437.pdf accessed 28 November 2017.

${ }^{45}$ See Part I on Agricultural Policies above.

46 (i) On 23 March 2017, participants from Nigeria attended a UPOV Office presentation on "Protection of New Plant Varieties under the UPOV Convention" at the WIPO-WTO Advanced Course on Intellectual Property for Government Officials held at the WIPO headquarters; (ii) On 20 June 2017, participants from Nigeria attended a training session on UPOV at the 20th International Course on Plant Variety Protection organized by Naktuinbouw. Before the course, the students participated in the UPOV distant learning course DL-205; (iii) On 27 June 2017, participants from Nigeria attended a UPOV Office presentation on the Implementation of the International Convention for the Protection of New Plant Varieties (UPOV' at the WIPO-WTO Colloquium for Teachers of Intellectual Property held at the WTO headquarters in Geneva; (iv) On 30 June 2017, participants from Nigeria attended the WIPO-UNIGE Summer School on Intellectual Property, where the UPOV Office made a presentation on "The Protection of Plant Varieties and the International Union for the Protection of New Varieties" of Plants' held at the WIPO headquarters in Geneva; and (v) On 20 and 21 July 2017, participants from Nigeria attended lectures on plant variety protection under the UPOV system provided by Mr Doug Waterhouse, on behalf of the UPOV Office, at the WIPO-QUT Master of Intellectual Property Law at the Queensland University of Technology in Brisbane, Australia. See generally: UPOV, "Report on Activities during the First Nine Months of 2017" 51st Ordinary Session Geneva, 26 October 2017 (C/51/3, 20 October 2017).

47 See Articles 6-9 of the UPOV 1991 Convention fully set out the definitions of new, distinct, uniform and stable conditions.

${ }^{48}$ These further or other conditions include alternative conditions of protection such as "identifiability" which could be provided as a condition to protect small-scale farmers' varieties. See, for example, Articles 24 and 25 of the African Model Law.

${ }^{49}$ Small-scale farmers conserve and develop farmers' varieties using traditional processes and not modern or laboratory breeding processes. Therefore, the varieties developed by farmers are usually variable and assorted.

50 Section 15, PPVFRA.

${ }^{51}$ See Section 46 of the PVPA.

52 See also: Protection of Plant Varieties and Farmers Rights Authority, India: http://plantauthority.gov.in/

${ }^{53}$ See notes 13 and 14 above.

${ }^{54}$ For discussions on the interpretation of Article 30 of TRIPS, see the EC-Canada case (WT/DS114/R) 17 March 2000.

55 Monsanto Co v McFarling, Nos. 05-1570-1598 (Fed. Cir. 24 May 2007).

56 The Plant Varieties and Seeds Act 1964.

57 The NCVLBA and NASA do not provide legally enforceable exclusive rights over new plant varieties or seeds. Therefore, they do not qualify as IPRs as required under Article 27.3(b) of TRIPS (see generally Leskien \& Flitner, 1997).

${ }^{58}$ NACGRAB was established by Nigeria's Federal Ministry of Science and Technology in 1987, to conduct research, gather data and disseminate technological information on matters relating to genetic resources conservation, utilization and biotechnology applications.

${ }^{59}$ For individuals, naming or releasing crop varieties in Nigeria without the written authority of the Registrar of the NCVLBA is punishable by either a fine of up to NGN100,000, imprisonment, or both fine and imprisonment. In like manner, corporate bodies can be fined for up to NGN500,000. See the National Crop Varieties and Livestock Breed (Registration, ETC.) (Amendment) Act, 2016.

${ }^{60}$ NACGRAB, Guidelines for Registration and Release of New Crop Varieties in Nigeria (NACGRAB, 2016b). 
${ }^{61}$ NACGRAB, Guidelines for Registration and Release of New Crop Varieties in Nigeria 13-14.

62 Ibid.

${ }^{63}$ Section 21 of NASA.

64 Ibid.

${ }^{65}$ Public debates and protests on the design of plant variety protection systems in Thailand and India started in the late 1990 s.

${ }^{66}$ Nigeria has a bicameral legislature known as the National Assembly established under Section 4 of the 1999 Constitution of the Federal Republic of Nigeria. It consists of a Senate and a House of Representatives. For a snapshot of Bill processes in Nigeria, see PLAC Bills Tracking, Policy and Legal Advocacy Centre-Bill Processes http://placbillstrack.org/billprocess.php

${ }^{67} \mathrm{Hon}$ Agu is a member of the House of Representatives, belonging to the People's Democratic Party of Nigeria, and representing Enugu State, Nigeria.

${ }^{68}$ On Johnson Ekpere, see also note 31 above.

${ }^{69}$ Critical analysis of the IPC Bill is presented in a forthcoming article by the author.

70 See the discussion on implementation of the PVPA and PPVFRA in Part II above.

${ }^{71}$ Recall that the NCVLBA entered into force in 1987, and the NASA in 1992.

72 Ibid.

${ }^{73}$ Section 203 of the Intellectual Property Commission Bill, 2008 provides farmers' rights exceptions. Emphasis added to distinguish between both types of farmers' rights.

${ }^{74}$ Section 189 of the Intellectual Property Commission Bill, 2008 provides for private use and research exceptions.

${ }^{75}$ See Section 186 of the IPC Bill.

${ }^{76}$ Sections 191 and 192 of the Intellectual Property Commission Bill 2008 provide for government use and compulsory license exceptions to plant breeder's rights.

77 Recall that UPOV allows for the protection of only "new" varieties. See Article 6 of the UPOV 1991 Convention.

\section{ORCID}

Titilayo Adebola iD http://orcid.org/0000-0002-0552-2153

\section{REFERENCES}

A Bill for an Act to Provide for the Establishment of the Industrial Property Commission of Nigeria, Repeal of Trademarks Act Cap 436, LFN 1990 and Patents and Designs Act, Cap 344, LFN 1990 and Make Comprehensive Provisions for the Registration and Protection of Trademarks, Patents and Designs, Plant Varieties, Animal Breeders and Farmers' Rights and for Related Matters' (2016).

A Bill for an Act to Provide for the Establishment of the Intellectual Property Commission of Nigeria, Repeal of Trademarks Act Cap. T13, LFN 2004 And Patents and Designs Act, Cap. P2, LFN 2004 and Make Comprehensive Provisions for the Registration and Protection of Trademarks, Patents and Designs, Plant Varieties, Animal Breeders and Farmers Rights and For Other Related Matters (2006).

Adesina, A. (2013). Transforming Nigeria's Agriculture. Retrieved from http://agriculture.columbia.edu/events/past-events/ inaugural-seminar-the-nexus-of-agriculture-environment-and-livelihoods/transforming-nigerias-agriculture.

Adewopo, A. (2012a). The global intellectual property system and sub-Saharan Africa-A prognostic reflection. University of Toledo Law Review, 33, 749-770.

Adewopo, A. (2012b). According to Intellectual Property: A Pro-Development Vision of the Law and the Nigerian Intellectual Property Law and Policy Reform in the Knowledge Era (Nigerian Institute of Advanced Legal Studies).

Agreement on Trade-Related Aspects of Intellectual Property Rights (1994) Annex 1C, 33 ILM 81.

Agricultural Research Council of Nigeria. (2010). Strategic Plan 2011-2020.

Alter, K., \& Meunier, S. (2009). The politics of international regime complexity. Perspectives on Politics, 7(1), 13-24.

Andersen, R. (2016a). Historical context: Evolving international cooperation on crop genetic resources. In M. Halewood (Ed.), Farmers' crop varieties and farmers' rights: Challenges in taxonomy and law. London and New York: Earthscan.

Andersen, R. (2016b). Farmers' rights: Evolution of the international policy debate and national development. In M. Halewood (Ed.), Farmers' crop varieties and farmers' rights: Challenges in taxonomy and law. London and New York: Earthscan. 
Aoki, K. (2008). Seed Wars: Controversies and Cases on Plant Genetic Resources and Intellectual Property. Carolina Academic Press.

Aoki, K., \& Luvai, K. (2007). Reclaiming 'Common heritage' treatment in the international plant genetic resources regime complex. Michigan State Law Review, 35-70.

APBREBES. (2014). Massive Protects in Ghana over UPOV Style Plant Breeders' Bill. Retrieved from http://www.apbrebes. org/news/massive-protests-ghana-over-upov-style-plant-breeders-bill.

Ayoola, G. B. (2001). Essays on the agricultural economy: A book of readings on agricultural development policy and administration in Nigeria (Vol. 1). Ibadan, Nigeria: TMA Publishers.

Bentley, L. (2011). The "Extraordinary multiplicity" of intellectual property laws in the British colonies in the nineteenth century. Theoretical Inquiries in Law, 12(1), 161-200.

Bentley, J. W., Ajayi, O., \& Adelugba, K. (2011). Nigeria: Clustered seed companies. In P. V. Mele, J. Bentley, \& R. G. Guei (Eds.), African seed enterprises: Sowing seeds of the future. Food and Agriculture Organisation of the United Nations, AfricaRice Center, \& CAB International, Gutenberg Press, Malta.

Borowaik, C. (2004). Farmers' rights: Intellectual property regimes and the struggle over seeds. Politics and Society, 32(4), 511-543.

Bragdon, S., Garforth, K., \& Haapala, H. E., Jr. (2008). Safeguarding biodiversity: The convention on biological biodiversity (CBD). In G. Tansey, \& T. Rajotte (Eds.), The future control of food. London, Sterling, VA: Earthscan.

Campi, M., \& Dueñas, M. (2017). Intellectual Property Rights, Trade Agreements, and International Trade. Retrieved from https://papers.ssrn.com/sol3/papers.cfm?abstract_id= 3030826

Campi, M., \& Nuvolari, A. (2015). Intellectual property protection in plant varieties. A worldwide index (1961-2011). Research Policy, 44(4), 951-964.

Convention on Biological Diversity (1992) 1760 UNTS 143, 31 ILM 818.

Correa, C. M., Shashikant, S., \& Meienberg, F. (2015). Plant Variety Protection in Developing Countries: A Tool for Designing a Sui Generis Plant Variety Protection System: An Alternative to UPOV 1991. APBREBES. Working Paper.

Crucible Group. (1994). People, Plants and Patents: The Impact of Intellectual Property on Trade, Plant Biodiversity, and Rural Society. Ottawa, ON: The International Development Research Centre.

Crucible Group II. (2001). Seeding Solutions. Volume 2. Options for National Laws Governing Control over Genetic Resources and Biological Innovations. The International Development Research Centre, the International Plant Genetic Resources Institute and the Dag Hammarskjold Foundation.

Cullet, P. (2001). Plant variety protection in Africa: Towards compliance with the TRIPS Agreement. Journal of African Law, 45(1), 97-122.

Davis, J. H., \& Goldberg, R. A. (1957). A concept of agribusiness. Boston: School of Business Administration, Harvard University.

Deere, C. (2009). The Implementation Game: The TRIPS Agreement and the Global Politics of Intellectual Property Reform in Developing Countries. New York: Oxford University Press.

De Jonge, B. (2014). Plant variety protection in Sub-Saharan Africa: Balancing commercial and smallholder farmers' interests. Journal of Politics and Law, 7(3), 100-111.

Drahos, P. (1995). Global property rights in information: The story of TRIPS at the GATT. Prometheus, 13(1), 6-19.

Dutfield, G. (2000). Intellectual Property Rights, Trade and Biodiversity. Earthscan.

Dutfield, G. (2003). Intellectual Property Rights and the Life Sciences Industries: A Twentieth Century History. Ashgate Publishing Limited England. Ashgate Publishing Company USA.

Dutfield, G. (2008). Turning plant varieties into intellectual property: The UPOV Convention. In G. Tansey, \& T. Rajotte (Eds.), The Future control of food: A guide to international negotiations and rules on intellectual property, biodiversity and food security (pp. 27-47). London, Sterling, VA: Earthscan.

Dutfield, G. (2011). Food, Biological Diversity and Intellectual Property: The Role of the International Union for the Protection of New Varieties of Plants (UPOV) (Quaker United Nations Office, February 2011) Global Economic Issue Publications, Intellectual Property Issue Paper No 1.

Ekekewe, E. (1985). State and economic development in Nigeria. In A. Claude (Ed.), Political economy of Nigeria. Lagos \& London: Longman.

Ekpere, J. (2000). The OAU's Model Law: The Protection of the Rights of Local Communities, Farmers and Breeders, and for the Regulation of Access to Biological Resources, an Explanatory Booklet. OAU/STRC.

Ekpere, J. (2003). African model law on the protection of the rights of local communities, farmers and breeders, and for the regulation of access to biological resources. In K. Nnadozie, R. Lettington, C. Bruch, S. Bass, \& S. King (Eds.), African perspectives on genetic resources: A handbook on laws, policies and institutions. Washington DC: Environmental Law Institute.

Ex Parte Hibberd et al. (1985). 227 USPQ 443.

Favereto, A. (2016). Beyond Family Farming versus agribusiness' dualism: Unpacking the complexity of Brazil's agricultural model (Working Paper 138). China and Brazil in African Agriculture Working Paper Series. 
FAO Conference, Farmers' Rights Resolution 3/91, Annex to the International Undertaking on Plant Genetic Resources.

FAO Conference, Farmers' Rights Resolution 4/89, Annex to the International Undertaking on Plant Genetic Resources.

FAO Conference, Farmers' Rights Resolution 5/89, Annex to the International Undertaking on Plant Genetic Resources.

Fieldwork interview with FME Official (2015).

Fieldwork interview with CVRCN Officials (2015).

Food Sovereignty Ghana. (2013). Petition to Parliament on the Plant Breeders' Bill, 2013.' Retrieved from http:// foodsovereigntyghana.org/petition-to-parliament-on-the-plant-breeders-bill-2013/

Fowler, C. (1994). Unnatural Selection: Technology, Politics and Plant Evolution. Gordon and Breach.

Gagne, G., \& Ratanasatien, C. (2016). Commentary on Thailand's plant varieties protection act. In M. Halewood (Ed.), Farmers' crop varieties and farmers' rights: Challenges in taxonomy and law. London and New York: Earthscan.

Gervais, D. (1998). The TRIPS Agreement: Drafting History and Analysis. London: Sweet and Maxwell.

GRAIN. (1998). Ten Reasons not to join UPOV, Global Trade and Biodiversity in Conflict. Retrieved from https://www.grain. org/article/entries/1-ten-reasons-not-to-join-upov

Halewood, M., \& Nnadozie, K. (2008). Giving priority to the commons: The international treaty on plant genetic resources for food and agriculture. In G. Tansey, \& T. Rajotte (Eds.), The future control of food: A guide to international negotiations and rules on intellectual property. London, Sterling, VA: Earthscan.

Helfer, L. (2004a). Intellectual Property Rights in Plant Varieties, International Legal Regimes and Policy Options for National Governments. FAO Legislative Study 85.

Helfer, L. (2004b). Regime shifting: The TRIPS agreement and new dynamics of international intellectual property law making. Yale Journal of International Law, 29, 1-83.

Helfer, L. (2009). Regime shifting in the international intellectual property system. Perspectives on Politics, 7(1), 39-44.

Helleiner, G. (1966). Peasant Agriculture, Government, and Economic Growth in Nigeria. Illinois: Richard Irwin Inc.

IFAD. (2013). Smallholders, food security and the environment. Retrieved from https://www.ifad.org/documents/10180/ $666 c a c 24-14 b 6-43 c 2-876 d-9 c 2 d 1 f 01 d 5 d d$

International Centre for Trade and Sustainable Development. (2005). UNCTAD-ICTSD Project on IPRs and Sustainable Development: Resource Book on TRIPS and Development. New York: Cambridge University Press.

International Convention for the Protection of New Varieties of Plants 1961 International Convention for the Protection of New Varieties of Plants 1961, as revised in 1972, 1978 and 1991, 815 UNTS 89.

International Treaty on Plant Genetic Resources for Food and Agriculture. (2001, November 3). Res 3/2003 FAO Conference, 31st Session.

International Undertaking on Plant Genetic Resources (1983) FAO Resolution 8/83.

JEM AG Supply Inc, DBA Farm Advantage Inc et al. v Pioneer Hi-bred International Inc (2001) 534 US 124.

Kanniah, R. (2005). Plant variety protection in Indonesia, Malaysia, the Philippines and Thailand. The Journal of World Intellectual Property, 8(3), 283-310.

Kloppenburg, J. (2004). First the Seed: The Political Economy of Plant Biotechnology 1492-2000 (2nd edn.). Madison, Wisconsin: University of Wisconsin Press.

Kochupillai, M. (2016). Promoting Sustainable Innovations in Plant Varieties. Berlin Heidelberg: Springer-Verlag.

Kuanpoth, J. (2009). Pushing against globalization: The response from civil society groups in Thailand. In J. Gillespie, \& R. Peerenboom (Eds.), Regulation in asia: Pushing back on globalization. London and New York: Routledge.

Lertdhamtewe, P. (2017). Thailand's Sui Generis System of Plant Variety Protection. Paper Presented at South Asia Watch on Trade, Economics and Environment. Retrieved from http://sawtee.org/presentations/Presentation6_3Aug_2017.pdf

Leskien, D., \& Flitner, M. (1997). Intellectual Property Rights and Plant Genetic Resources: Options for a Sui Generis System. Issues in Genetic Resources No 6 International Plant Genetic Resources Institute, Rome, Italy.

Lianchamroon, W. (1998). Community rights and farmers' rights in Thailand. Biotechnology and Development Monitor, 36, 9-11.

Louwaars, N. P., Tripp R, Eaton D, Henson-Apollonio V, Hu. R, Mendoza. M, . . Wekundah, J. (2005). Impacts of Strengthened Intellectual Property Rights Regime on the Plant Breeding Industry in Developing Countries: A Synthesis of Five Case Studies. Report Commissioned by the World Bank Retrieved from https://www.iprsonline.org/resources/docs/ LouwaarsCGN_Plants_05.pdf

Lowder, S.K., Skoet, J., \& Singh, S. (2014). What do we really know about the number and distribution of farms and family farms worldwide? Background paper for the Food and Agriculture Organisation (ESA Working Paper No. 14-02). Rome: FAO.

Maskus, K., \& Ridley, W. (2016). Intellectual Property-Related Preferential Trade Agreements and the Composition of Trade (Research Paper No. 2016/ 35). Robert Schuman Centre for Advanced Studies.

Mgbenka, R. N., \& Mbah, E. N. (2016). A review of smallholder farming in Nigeria: Need for transformation. International Journal of Agricultural Extension and Rural Development Studies, 3(2), 54.

Mooney, P. (2011). International non-governmental organizations: The hundred year (or so) seed war-Seeds, sovereignty and civil society-A historical perspective on the evolution of 'The law of the seed'. In C. Frison, F. Lopez, \& J. T. Esquinas-Alcazar (Eds.), 
Plant genetic resources and food security: Stakeholder perspectives on the international treaty on plant genetic resources for food and agriculture. London and New York: Earthscan.

Murphy, S. (2012). Changing Perspectives: Small-scale farmers, markets and globalisation. International Institute for Environment and Development/HIVOS.

NACGRAB. (2016a). Guidelines for Registration and Release of New Crop Varieties in Nigeria. NACGRAB. Retrieved from http://www.nacgrab.gov.ng/images/Guidelines\%20for\%20Crop\%20Varietal\%20Release.pdf

NACGRAB. (2016b). Varieties Release Catalogue. NACGRAB. Retrieved from http://www.nacgrab.gov.ng/images/ Varieties_Released_Catalogue.pdf

Nagoya Protocol on Access to Genetic Resources and the Fair and Equitable Sharing of Benefits Arising from their Utilization to the Convention on Biological Diversity (2010).

National Agricultural Seeds Act 1992, CAP N5, Laws of the Federation of Nigeria (2004).

National Agricultural Seeds Council. (2014). National Agricultural Seeds Council Annual Report. Retrieved from http:// seedcouncil.gov.ng/uploads/2017/02/2014_annual_report.pdf

National Crop Varieties and Livestock Breeds (Registration, etc.) Act 1987, CAP N27, Laws of the Federation of Nigeria (2004).

National Environmental (Access to Genetic Resources and Benefit Sharing) Regulations (2009).

Nnadozie, K., Lettington, R., Bruch, C., Bass, S., \& King, S. (2003). African perspectives on genetic resources: A handbook on laws, policies and institutions. Washington DC: Environmental Law Institute.

Nwokocha, U. (2012). Nigerian intellectual property: Overview of development \& practice. NIALS Journal of Intellectual Property, 101-116.

Ogbalubi, L. N., \& Wokocha, C. C. (2013). Agricultural development and employment generation: The Nigeria experience. IOSR Journal of Agriculture and Veterinary Science, 2, 60-69.

Oguamanam, C. (2015). Breeding apples for oranges: Africa's misplaced priority over plant breeders' rights. The Journal of World Intellectual Property, 18(5), 165-195.

Okediji, R. (2003). The international relations of intellectual property: Narratives of developing country participation in the global intellectual property system. Singapore Journal of International and Comparative Law, 7, 315-385.

Organisation of African Unity's Model Law for the Protection of the Rights of Local Communities, Farmers and Breeders and for the Regulation of Access to Biological Resources (2000).

Patents and Designs Act (1970).

Peschard, K. (2014). Farmers' rights and food sovereignty: Critical insights from India. The Journal of Peasant Studies, 41(6), 1085-1108.

Pistorius, R., \& Wijk, J. V. (1999). The exploitation of plant information: Political strategies in crop development. New Zealand and the Hague: CABI Publishing.

Plahe, J. K. (2011). TRIPS downhill: India's plant variety protection system and implications for small farmers. Journal of Contemporary Asia, 41(1), 75-98.

Plant Patent Act (1930).

Plant Varieties Protection Act B E 2542 (1999).

Protection of Plant Varieties and Farmers Rights Act (2001).

Ramanna, A. (2006). Farmers rights in India: A case study. Norway: The Fridtjof Nansen Institute.

Ramanna, A., \& Smale, M. (2004). Rights and access to plant genetic resources under India's new law. Development Policy Review, 22(4), 423-442.

Rangnekar, D. (2002). Access to Genetic Resources, Gene-based Inventions and Agriculture. Study Paper 3a, United Kingdom Commission on Intellectual Property Rights.

Rangnekar, G. (2013). Geneva rhetoric, national reality: The political economy of introducing plant breeders' rights in Kenya. New Political Economy, 19(3), 359-383.

Rangnekar, D. (2014). Geneva rhetoric, national reality: The political economy of introducing plant breeders' rights in Kenya. New Political Economy, 19(3), 359-383.

Raustiala, K., \& Victor, D. (2004). The regime complex for plant genetic resources. International Organization, 58(2), 277-309.

Roffe, P. (2008). Bringing minimum global intellectual property standards into agriculture: The agreement on trade-Related aspects of intellectual property rights (TRIPS). In G. Tansey, \& T. Rajotte (Eds.), The future control of food. London, Sterling, VA: Earthscan.

Sandersen, J. (2017). Plants, people and practices: The nature and history of the UPOV convention. New York: Cambridge University Press.

Diamond, S. A., Commissioner of Patents and Trademarks v., Chakrabarty, A. M., et al. (1980) 447 US 303.

Sodipo, B. (1994). Piracy and counterfeiting, GATT, TRIPS and developing countries. London and Boston: Kluwer.

Strba, S. I. (2017). Legal and institutional considerations for plant variety protection and food security in African development agendas: Solutions from WIPO? Journal of Intellectual Property Law and Practice, 12(3), 191-205. 
The Agriculture Promotion Policy (2016-2020). The Federal Republic of Nigeria.

The Copyright Act 1970.

The Trademarks Act 1965.

The World Bank. (2016). Agriculture, Value Added: \% of GDP 2016. Retrieved from https://data.worldbank.org/indicator/ NV.AGR.TOTL.ZS?locations = NG

The World Bank. (2017). Employment in Agriculture (\% of total employment) (modelled ILO estimate. Retrieved from https:// data.worldbank.org/indicator/SL.AGR.EMPL.ZS

Transformation Agenda. (2011-2015). The Federal Republic of Nigeria.

UPOV. (2005). UPOV Report on the Impact of Plant Variety Protection. Retrieved from http://www.upov.int/export/sites/ upov/about/en/pdf/353_upov_report.pdf

UPOV. (2017). States and Intergovernmental Organizations which have been in contact with the Office of the Union for Assistance in the Development of Law based on the UPOV Convention. Retrieved from http://www.upov.int/export/ sites/upov/members/en/pdf/status.pdf

Van Overwalle, G. (1999). Patent protection for plants: A comparison of American and European approaches. IDEA Journal of Law and Technology, 39, 143-194.

Watal, J. (2000). Intellectual property rights in the WTO and developing countries. The Hague: Kluwer Law International.

WIPO-IGC. (2018). The WIPO- Intergovernmental Committee on Intellectual Property, Genetic Resources and Traditional Knowledge. Retrieved from http://www.wipo.int/tk/en/igc/

Yu, P. (2007). International enclosure, the regime complex, and intellectual property Schizophrenia. Michigan State Law Review, 1, 1-33.

Zerbe, N. (2005). Biodiversity, ownership, and indigenous knowledge: Exploring legal frameworks for community, farmers, and intellectual property rights in africa. Ecological Economics, 53, 493- 506.

Zylbersztajn, D. (2017). Agribusiness systems analysis: Origin, Evolution and Research Perspectives. Revista de Administracao (Sao Paulo), 52(1), 114-117.

How to cite this article: Adebola T. Examining plant variety protection in Nigeria: Realities, obligations and prospects. J World Intellect Prop. 2018;1-23. https://doi.org/10.1111/jwip.12113 